\title{
Különleges nanoszerkezetü amfifil kotérháló alapú gélek és nanohibridjeik
}

\author{
IVÁN Béla ${ }^{a^{*}}$, SZABÓ Ákos $^{\mathrm{a}}$, DOMJÁN Attila ${ }^{\mathrm{b}}$, ERDÖDI Gábor ${ }^{\mathrm{a}}$, FODOR Csaba ${ }^{\mathrm{a}}$, \\ HARASZTI Márton ${ }^{\mathrm{a}}$, KALI Gergely ${ }^{\mathrm{a}}$, MEZEY Péter ${ }^{\mathrm{a}}$, OSVÁTH Zsófia ${ }^{\mathrm{a}}$, PÁSZTOR Szabolcs ${ }^{\mathrm{a}}$, \\ STUMPHAUSER Tímea ${ }^{\mathrm{a}}$, TÓTH Tamás ${ }^{\mathrm{a}}$, VARGA Bence ${ }^{\mathrm{a}, \mathrm{c}}$, BÓTA Attila ${ }^{\mathrm{d}}$, WACHA András ${ }^{\mathrm{d}}$, \\ Ralf THOMANN $^{\mathrm{e}}$, Yi THOMANN ${ }^{\mathrm{e}}$, Rolf MÜLHAUPT ${ }^{\mathrm{e}}$ \\ ${ }^{a}$ MTA TTK AKI Polimer Kémiai Kutatócsoport, 1117 Budapest, Magyar tudósok körútja 2., Magyarország \\ ${ }^{b}$ MTA TTK SZKI NMR Kutatócsoport, 1117 Budapest, Magyar tudósok körútja 2., Magyarország \\ ${ }^{c}$ ELTE TTK Kémia Doktori Iskola, 1117 Budapest, Pázmány Péter sétány 2, Magyarország \\ ${ }^{d}$ MTA TTK AKI Biológiai Nanokémia Kutatócsoport, 1117 Budapest, Magyar tudósok körútja 2., Magyarország \\ 'Albert-Ludvigs-Universität Freiburg, Freiburger Materialforschungszentrum, \\ Stefan-Meier-Str. 21., D-79104 Freiburg, Németország
}

\section{Bevezetés}

Napjainkban rendkívül intenzív kutatás-fejlesztés folyik a nanoszerkezetü anyagok terén világszerte. Az ilyen szerkezetü anyagok máris számos területen alkalmazásra kerültek, és az előrejelzések szerint az elöttünk álló évszázadban megjósolt ipari forradalom kulcsanyagai között tartják számon ezeket. Ide tartoznak a nanométer tartományban elkülönülő fázisokból felépülő amfifil polimer kotérhálók (APCN) is. ${ }^{1-14} \mathrm{Az}$ APCN-ekben, szemben a hagyományos, kis molekulatömegü térhálósító szerekkel keresztkötött térhálós polimerekkel (pl. vulkanizált gumik, epoxik, sztirol-divinilbenzol gyanták stb.), különböző filicitású (jellemzően hidrofil és hidrofób) polimer láncok kapcsolódnak egymáshoz kovalens kötéssel. Mivel a kémiai kötés meggátolja az eltérő filicitású polimer láncok makroszkopikus szételegyedését, különleges nanoszerkezetü morfológiai felépítésű anyagokhoz juthatunk ilyen módon. Kontaktlencseként ezen anyagok egyik széleskörü alkalmazását képezik a jó oxigénáteresztő képességgel rendelkező poli(dimetilsziloxán)t (PDMS) tartalmazó APCN-ek. ${ }^{15-17}$

Az egymással nem elegyedő komponensek miatt az APCN-ek előállítása számos esetben komoly szintetikus kihívást jelent. Ezért a legtöbb publikált APCN elöállítása az összetevők és a keletkező anyagok közös oldószerében történik. Három fö szintézisutat különböztethetünk meg: (1) makromonomer módszer, amelyet a leggyakrabban alkalmaznak, és amely telekelikus makromonomerek (polimerizálható funkciós csoportokat tartalmazó polimerek) többnyire gyökös kopolimerizációját jelenti arra alkalmas monomerekkel ${ }^{1-3,11-17}$ (1. ábra); (2) szekvenciális élő polimerizáció és azt követő térhálósítás ${ }^{6,7}$ (2. ábra); (3) megfelelö funkciós csoportokkal rendelkező polimer láncok összekapcsolása ${ }^{4,5,8,18,19}$ (3.ábra). A makromonomer módszer alkalmazásának egyik legfőbb előfeltétele az, hogy megfelelő szerkezetű funkciós makromonomerek álljanak rendelkezésre. Az élő polimerizáció terén az utóbbi időben bekövetkezett robbanásszerü fejlődés számos lehetőséget kínál ezek szintézisére. Az egyik ilyen makromonomer a metakrilát-telekelikus poliizobutilén (MA-PIB-MA), amely kváziélő karbokationos polimerizációval ${ }^{2,20,21}$ és azt követő kvantitatív láncvégi funkcionalizálással állítható elő (4. ábra). A telekelikus PIB nagy érdeklődésre számot tartó polimer, mivel telített szénhidrogén szerkezetének és oldallánci metil-csoportjainak köszönhetően több előnyös tulajdonsággal is rendelkezik, pl. erősen hidrofób, kis üvegesedési hőmérsékletü, kémiailag inert, jó gázzáró képességü, és nem utolsósorban biokompatibilitis anyag. Ez utóbbinak is köszönheti nagy hozzáadott értékü alkalmazásait, például a gyógyszerkibocsátó koszorúér sztentek bevonóanyaga komponenseként. ${ }^{22}$ Kotérhálók makromonomer módszerrel történő szintéziséhez alkalmazott további biokompatibilis polimerek közé tartozik a már említett PDMS ${ }^{15-17}$ és a poli(tetrahidrofurán) (PTHF). ${ }^{3,23-28}$ Mindkettőt kváziélő gyürüfelnyílásos polimerizációval állítják elő. A PDMS-t oktametilciklotetrasziloxán (D4), míg a PTHF-et tetrahidrofurán (THF) polimerizációjával nyerik. Az utóbbi időben egyre nagyobb érdeklődés mutatkozik az olyan kotérhálók iránt, amelyekben az egyik komponens egy térhálós vagy elágazó szerkezetü szervetlen makromolekuláris anyag, míg a másik szerves polimer, mint pl. a szilikagél-szerü részecskékkel szol-gél eljárással térhálósított termoreszponzív (intelligens) poli(N-izopropil-akrilamid) (PNIPAAm) alapú kotérhálók. ${ }^{37}$

Ebben a közleményben az amfifil kotérhálók, elsősorban a metakrilát-telekelikus poliizobutilén (MA-PIB-MA) és poli(tetrahidrofurán (MA-PTHF-MA) makromonomereken, valamint a PNIPAAm-on alapuló hibrid szerkezetủ amfifil polimer kotérhálókkal kapcsolatos eddigi fóbb eredményeinket foglaljuk össze.

\footnotetext{
* Tel.: +36-1-382-6512; e-mail: ivan.bela@ttk.mta.hu

A közlemény a Magyar Tudomány Ünnepe keretében az MTA Kolloidkémiai Munkabizottság megalakulásának 50. évfordulója alkalmából 2016. november 9-én rendezett ünnepi ülésen elhangzott előadás rövidített változata.
} 


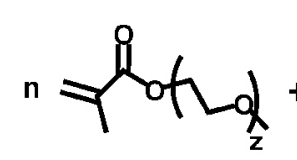<smiles>C=C(C)C(=O)OCCCOC(=O)C(=C)C</smiles>

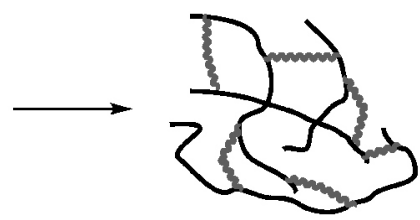

1. ábra: Poli(poli(etilén-glikol)-metakrilát)-l-poliizobutilén (PPEGMA-l-PIB) amfifil polimer kotérhálók előállítása makromonomer módszerrel ${ }^{1-3,11-17,23-28}$

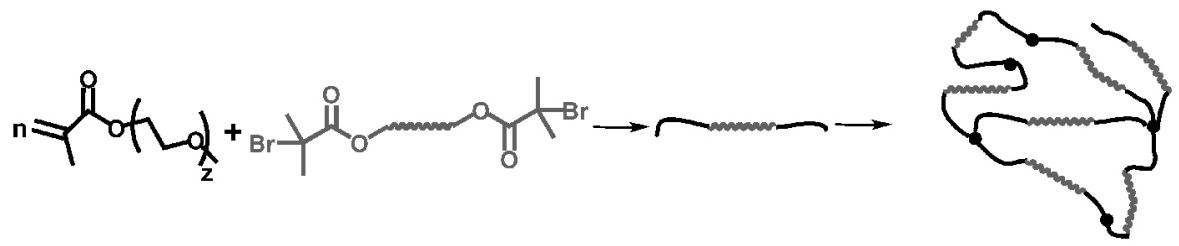

2. ábra: Amfifil polimer kotérhálók elóállítása szekvenciális polimerizációval és azt követő térhálósítással ${ }^{6,7}$

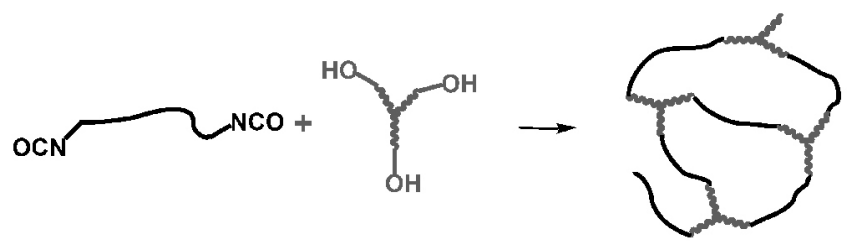

3. ábra: Amfifil polimer kotérhálók szintézise funkciós csoportokkal rendelkező polimer láncok összekapcsolásával 4,5,8,18,19

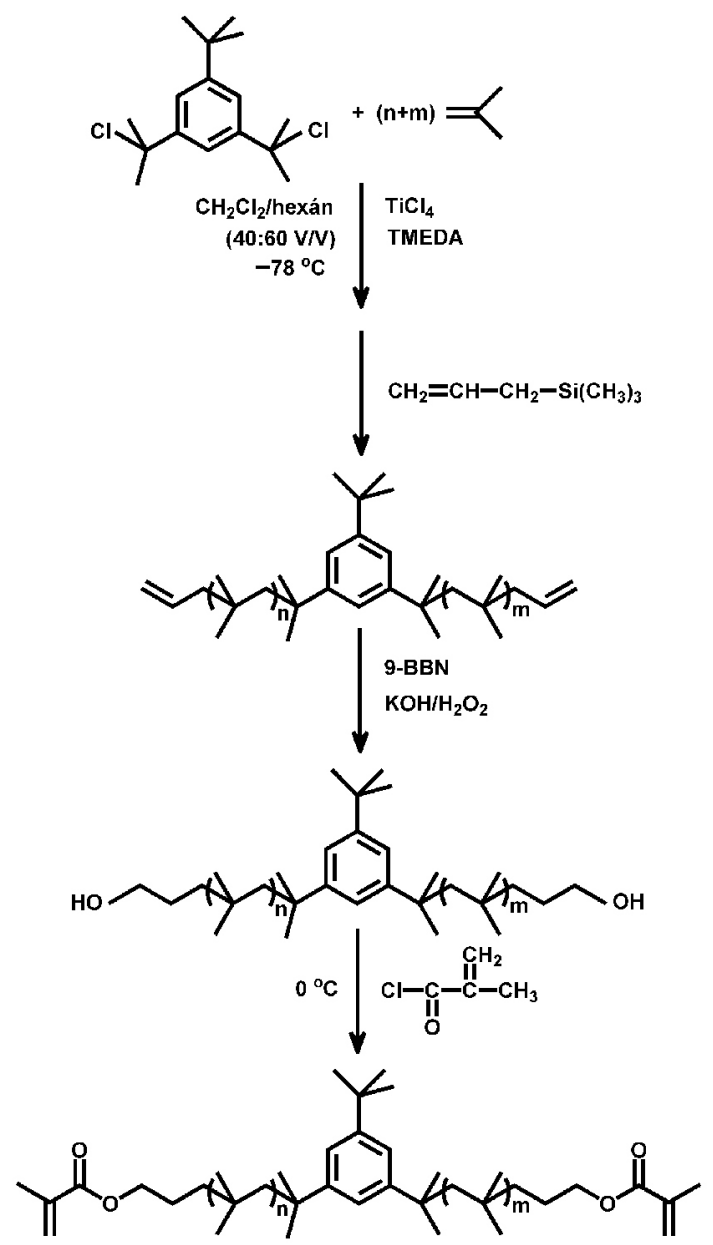

4. ábra: Metakrilát-telekelikus poliizobutilén (MA-PIB-MA) előállítása kváziélő karbokationos polimerizációval és azt követő allilálással, hidroborálással és észterezéssel ${ }^{2,20,21}$

124. évfolyam, 4. szám, 2018. 


\section{Az amfifil kotérhálók nanofázisú szerkezete}

Az amfifil kotérhálók szerkezete és így tulajdonságaik szempontjából is a legmeghatározóbb tényező az egymással nem elegyedő, kovalens kötéssel egymáshoz kapcsolt hidrofil és hidrofób polimer láncok térbeli elrendeződése, azaz morfológiája. Dinamikus pásztázó kalorimetriás (DSC) vizsgálatok azt az eredményt adták, hogy a kotérhálók a legtöbb esetben két, a kotérhálót alkotó polimerek homopolimerjeiéhez közeli üvegesedési hőmérséklettel rendelkeznek (5. ábra). ${ }^{1-3,11-13,23} \mathrm{Ez}$ egyértelműen arra utal, hogy az amfifil kotérhálók komponensei két elkülönülő fázisban helyezkednek el.

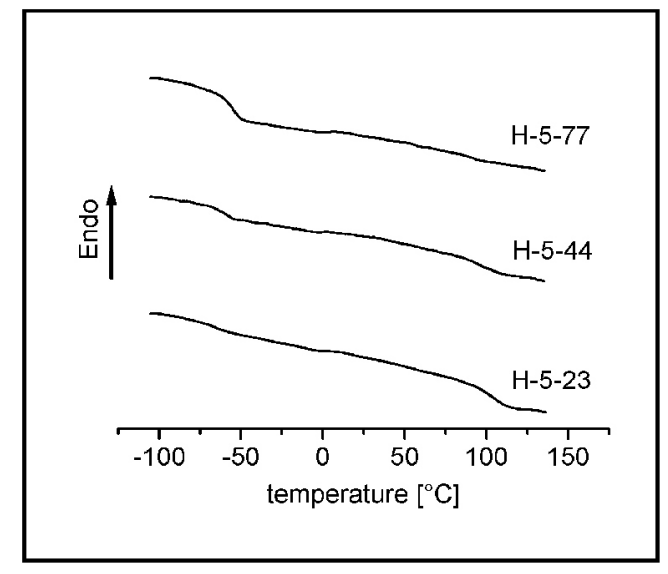

5. ábra: Poli(2-hidroxietil-metakrilát)-l-poliizobutilén (PHEMA-l-PIB) kotérhálók DSC görbéi

Kisszögű röntgenszórásos $(\mathrm{SAXS}),{ }^{1,4,8,12,13}$ kisszögü neutronszórásos (SANS), ${ }^{2,7}$ valamint spin-diffúziós szilárdtest $\mathrm{NMR}^{12}$ vizsgálatok eredményei egyértelmüen arra utalnak, hogy az elkülönülö fázisok az amfifil kotérhálókban 2-50 nm átlagos doménmérettel rendelkeznek, azaz nanofázisszerkezetű anyagok képződnek az előállításuk során. Az atomerő mikroszkópia (AFM) biztosítja azt a lehetőséget, hogy képet kaphassunk nemcsak a nanofázisok méretéről, de egymáshoz viszonyított helyzetéről is. ${ }^{1,3,9,13,14}$ Kiderült ezen vizsgálatok során, hogy a makromonomer módszerrel előállított amfifil kotérhálók morfológiája jelentős mértékben függ az összetételtől. Kis keresztkötőtartalom esetén a keresztkötő közel szférikus elrendezésben helyezkedik el a nagyobb mennyiséget képviselő másik összetevő mátrixában, majd a keresztkötő makromonomer mennyiségének növekedésével egyre inkább összefüggő fázist alkot ez a komponens. Az egyik legfontosabb eredménye ezeknek a vizsgálatoknak, hogy meglepően széles összetételtartományban kölcsönösen folytonos elrendezésben található a két nanofázis. Egy ilyen nanofázisú morfológiával rendelkező kotérháló, a poli(2-hidroxietil-metakrilát)-l-poliizobutilén (PHEMA-lPIB) AFM képét mutatja a 6. ábra. (A kotérhálók elnevezésében az ,l" az angol ,, linked by”, vagyis a „térhálósítva a következővel” kifejezés rövidítése.) Jól kivehető a 6. ábráról, hogy mind a PIB, mind pedig a PHEMA fázisok mérete a $10 \mathrm{~nm}$ körüli tartományba esik, és így az átlagos doméntávolság ezekben a kotérhálókban 20 nm körüli értéknek adódik, mint ahogy azt $\mathrm{SAXS}^{12,13}$ és spin diffúziós szilárdtest $\mathrm{NMR}^{13}$ mérések is igazolták ugyanezen kotérhálók esetében. Tekintettel arra, hogy blokkkopolimerek önrendeződése során hasonló, vagyis kölcsönösen folytonos morfológiát csak igen szük molekulatömeg- és összetételtartományban lehet elérni, ami ráadásul könnyen megbomlik hő vagy mechanikai hatásra, az amfifil kotérhálók stabil kölcsönösen folytonos nanofázisú morfológiája igen fontos eredmény, amely a legkülönfélébb alkalmazásokat eredményezheti. Nagyobb keresztkötőtartalom esetén pedig a másik összetevő jelenik meg elkülönülő szférikus jellegű fázisokban.

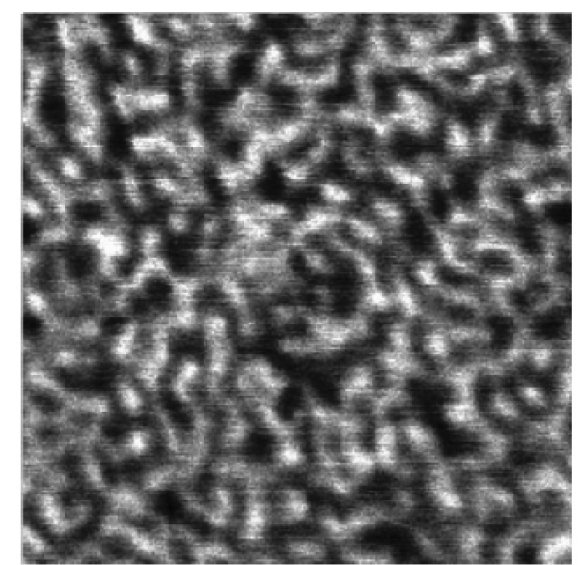

6. ábra: Poli(2-hidroxietil-metakrilát)-l-poliizobutilén (PHEMA-l-PIB) kotérháló (57 \% PIB) atomerő mikroszkópos képe (250×250 nm) (a sötétebb részek a PIB, a világosabbak a PHEMA fázisokat jelölik)

\section{Az amfifil kotérhálók duzzadási sajátságai}

Az amfifil kotérhálók összetevőinek hidrofil és hidrofób tulajdonságai alapján az lenne várható, hogy ezek az anyagok képesek mind hidrofil, mind pedig hidrofób anyagokkal kölcsönhatásba lépni. Ennek igazolása céljából szisztematikus duzzadási kísérleteket végeztünk mind poláris (hidrofil), mind apoláris (hidrofób) oldószerekkel többféle amfifil kotérhálóval is. 1,3,12,13,19,23,25,28-30 Egyértelműen igazolódott, hogy az amfifil kotérhálók valóban amfifil jellegüek, és összetételtől függő mértékben képesek duzzadni mind poláris, mind pedig apoláris oldószerekben. Jól tükrözi ezt a 7. ábra, amelyen makromonomer módszerrel előállított poli(dimetilakrilamid)-l-poliizobutilén (PDMAAm-l-PIB) kotérhálók tömeg szerinti duzzadási fokai láthatók vízben és heptánban az összetétel (PIB tartalom) függvényében. Ezek az eredmények egyértelműen mutatják, hogy a hidrofób PIB-tartalom növekedésével nő a heptánban mért duzzadási fok, a vízben mért pedig csökken. ${ }^{29} \mathrm{Az}$ is megfigyelhetö, hogy a köztes, azaz $\sim 50-70 \%$ PIB-et tartalmazó kotérhálókban mind a poláris (víz), mind pedig az apoláris (heptán) oldószerben képesek duzzadni ezek a kotérhálók. Ez az összetételtartomány jól egybeesik a kotérhálók azon összetételi tartományával, ahol kölcsönösen folytonos nanofázisú morfológiával rendelkeznek. Mindezek alapján kijelenthető az is, hogy az amfifil kotérhálók közegtől függően képesek hidrogélként vagy hidrofób gélként (liogélként) viselkedni. Ez az alapvető tulajdonságuk, azaz egy anyagban két eltérő tulajdonság ötvözése többféle speciális alkalmazási lehetőséget is előrevetít. 


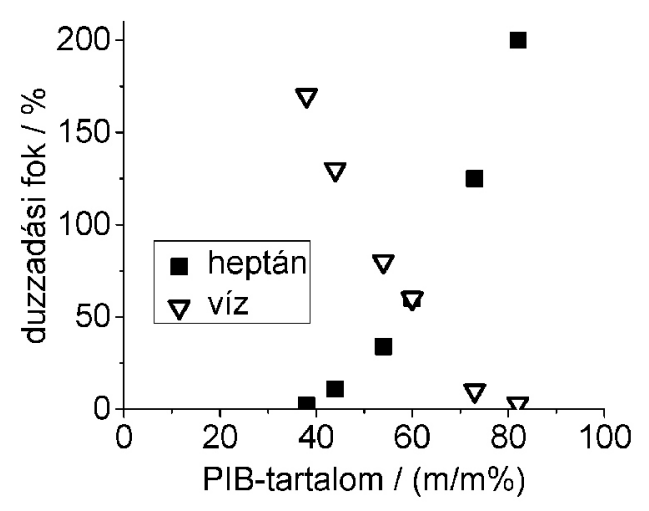

7. ábra: PDMAAm-l-PIB kotérhálók egyensúlyi duzzadási foka vízben és heptánban a PIB tartalom függvényében ${ }^{29}$

Meg kell említeni azt is, hogy az amfifil kotérhálók duzzadási kinetikája eltér a hidrogéleknél tapasztaltaktól. Pozitronannihilációs mérésekkel azt találtuk, hogy a duzzadás kezdeti szakaszában a víz viszonylag gyorsan eljut a hidrofil fázisba, majd ezt követően történik a hagyományosnak tekintett diffúziókontrollált duzzadás. ${ }^{31}$ Időfüggő duzzadásvizsgálatokkal, valamint szilárd NMR és pozitronannihilációs mérésekkel anomális, négy elkülöníthető szakasszal rendelkező duzzadási mechanizmust sikerült kimutatni poli(N-vinilimidazol)l-politetrahidrofurán (PNVIm-l-PTHF) kotérhálókban. ${ }^{25}$

\section{Amfifil kotérhálókon alapuló nanohibridek}

Az amfifil kotérhálók sajátos nanoszerkezete és duzzadási tulajdonságaik alapján adódik az a lehetőség, hogy a kotérháló egyik vagy külön-külön akár mindegyik fázisába szervetlen (vagy szerves) anyagból álló nanorészecskéket építsünk be. Ez azt jelenti, hogy a kotérháló egyik fázisát szelektíven duzzasztva, azt nanotemplátként (nanoreaktorként) alkalmazzuk, és a kiválasztott fázisban megfelelő reakcióval nanorészecskéket állítsunk elő. Ezesetben a másik fázis mintegy a nanoreaktor falaként viselkedik, és így biztosítja a nanométeres mérettartományba eső karakterisztikus méretet, valamint egyúttal meggátolja a képződő anyag makroszkópikus méretű aggregációját. Kotérháló-fém nanohibridek előállításának a sémáját mutatja a 8. ábra.

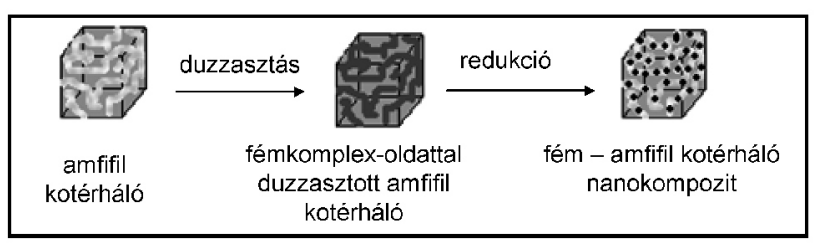

8. ábra: Fém nanorészecskék előállítása amfifil kotérhálókkal mint nanotemplátokkal (nanoreaktorokkal)

A fentebb leírt módon sikerült például PHEMA-l-PIB kotérhálókban kadmium-szulfid ${ }^{13}$ és arany, ${ }^{32}$ PDMAAml-PIB kotérhálókban ezüst ${ }^{29}$ és arany, ${ }^{32}$ valamint a PNVIm-l-PTHF kotérhálókban ${ }^{33}$ ezüst, réz, vas-oxid, továbbá palládium ${ }^{34}$ nanorészecskéket előállítani. A 9. ábrán egy tipikus kotérháló-fém (arany) nanohibrid transzmissziós elektronmikroszkópiás (TEM) felvétele látható. Ez egyértelmüen igazolja a fém nanorészecskék keletkezését. Meg kell jegyeznünk, hogy a fém nanorészecskék átlagos mérete meglepően jó egyezést mutat az adott amfifil kotérháló hidrofil nanofázisának a doménméretével. Ez egyértelmüen igazolja, hogy a kotérháló valóban mintegy nanoreaktorként müködik ezekben az esetekben. Ismeretes, hogy a fém nanorészecskék többféle sajátos tulajdonsággal is rendelkeznek a nagyobb méretü (tömb) megfelelöjükhöz képest. Az egyik ilyen sajátságuk több esetben is a megnövekedett katalitikus aktivitásuk. Az eddig vizsgált kotérháló-fém nanohibridekben képződött fém nanorészecskék valóban jelentős katalitikus aktivitást mutattak a nitrobenzol nátrium-borohidrides redukciójában mint modellreakcióban. ${ }^{29,32,33}$

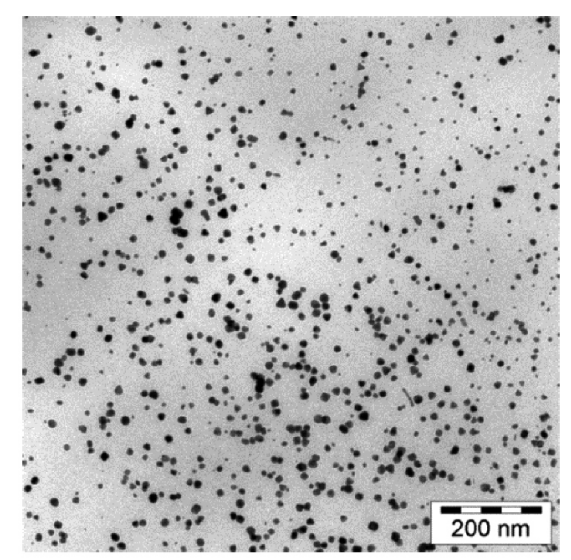

9. ábra: PHEMA-l-PIB amfifil kotérhálóban mint nanotemplátban előállított arany nanorészecskék transzmissziós elektronmikroszkópiás (TEM) képe

\section{Amfifil kotérháló alapú szabályozott gyógyszerleadó rendszerek}

Már az amfifil polimer kotérhálókkal kapcsolatos kezdeti kutatásoknak is egyik jól kijelölt célja volt olyan kotérhálók vizsgálata, amelyek biokompatibilis összetevőkből állnak és képesek valamely hatóanyag (gyógyszer) elnyújtott idejü, szabályozott leadására. ${ }^{34-36}$ Ebben a vonatkozásban különösen jelentősnek tünnek az olyan kotérhálók, amelyek úgynevezett reszponzív (intelligens) tulajdonsággal rendelkeznek. Leginkább a termoreszponzív ${ }^{37}$ és pH-reszponzív ${ }^{38-41}$ kotérhálók tünnek ebből a szempontból kiemelkedő fontosságúnak. Utóbbi az élő szervezetben, például gyomor-béltraktus közötti pH-különbség, míg a termoreszponzív anyagok a testhőmérséklet változásának hatására képesek más-más sebességgel és dózisban leadni a hatóanyagot. Ennek egyik legutóbbi példája a szol-gél módszerrel előállított termoreszponzív poli(N-izopropilakrilamid) alapú szerves-szervetlen gélek gyógyszerleadó képességének változása a hőmérséklettel (10. ábra). ${ }^{37}$ 


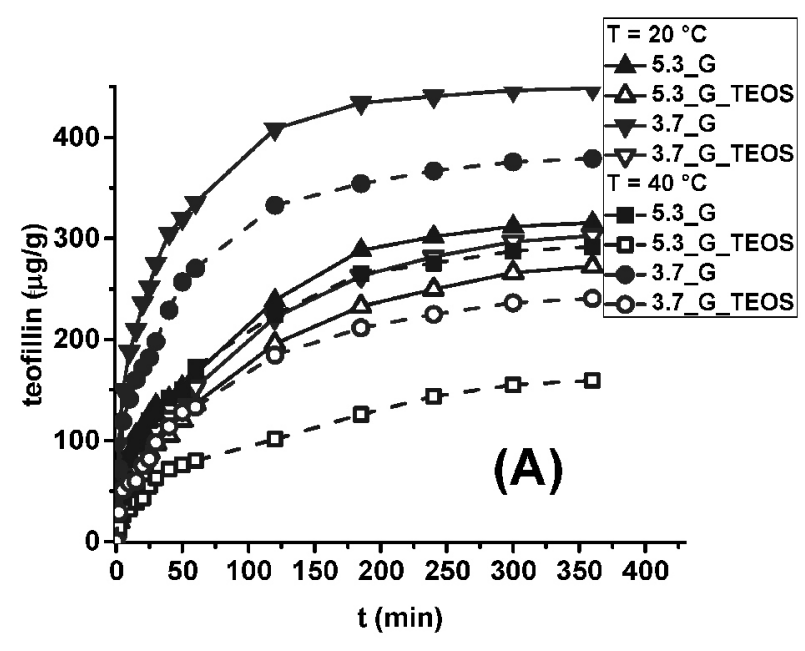

10. ábra: Poli(N-izopropil-akrilamid-ko-trimetoxi-szililpropil-metakrilát (P(NIPAAm-ko-TMSPMA)) alapú hibrid kotérháló alapú hidrogélek teofillinleadása $20^{\circ} \mathrm{C}$ és $40{ }^{\circ} \mathrm{C}$ hőmérsékleteken az idő függvényében (a számok a TMSPMA tartalmat mol\%-ban, a TEOS pedig a tetraetoxi-szilán tarlamú hibrid kotérhálókat jelöli) ${ }^{37}$

\section{Hivatkozások}

1. Iván, B.; Haraszti, M.; Erdődi, G.; Scherble, J.; Thomann, R.; Mülhaupt, R. Macromol. Symp. 2005, 227, 265-273. https://doi.org/10.1002/masy.200550926

2. Iván, B.; Almdal, K.; Mortensen, K.; Johannsen, I.; Kops, J. Macromolecules 2001, 34, 1579-1585.

https://doi.org/10.1021/ma000062+

3. Fodor, Cs.; Kali, G.; Thomann, R.; Thomann, Y.; Iván, B.; Mülhaupt, R. RSC Advances 2017, 7, 6827-6837. https://doi.org/10.1039/C6RA25356C

4. McLeod, K. R.; Tew, G. N. Macromolecules 2017, 50, 8042-8047. https://doi.org/10.1021/acs.macromol.7b01681

5. Nakagawa, S.; Li, X.; Kamata, H.; Sakai, T.; Gilbert, E. P.; Shibayama, M. Macromolecules 2017, 50, 3388-3395. https://doi.org/10.1021/acs.macromol.7b00486

6. Zhang, X.; Kyriakos, K.; Rikkou-Kalourkoti, M.; Kitiri, E. N.; Patrickios, C. S.; Papadakis, C. M. Colloid Polym. Sci. 2016, 294, 1027-1036. https://doi.org/10.1007/s00396-016-3856-0

7. Kali, G.; Georgiou, T. K.; Iván, B.; Patrickios, C. S.; Loizou, E.; Thomann, Y.; Tiller, J. C. Langmuir 2007, 23, 10746-10755. https://doi.org/10.1021/la7012478

8. Binder, W. H.; Petraru, L.; Roth, T.; Groh, P. W.; Pálfi, V.; Kéki, S.; Iván, B. Adv. Funct. Mater. 2007, 17, 1317-1326. https://doi.org/10.1002/adfm.200601084

9. Bruns, N.; Scherble, J.; Hartmann, L.; Thomann, R.; Iván, B.; Mülhaupt, R.; Tiller, J. C. Macromolecules 2005, 38, 2431-2438. https://doi.org/10.1021/ma047302w

10. Groenewolt, M.; Brezesinski, T.; Schlaad, H.; Antonietti, M.; Groh, P. W.; Iván, B. Adv. Mater. 2005, 17, 1158-1162. https://doi.org/10.1002/adma.200401549

11. Kali, G.; Vavra, Sz.; László, K.; Iván, B. Macromolecules 2013, 46, 5337-5344. https://doi.org/10.1021/ma400535r

12. Domján, A.; Erdődi, G.; Wilhelm, M.; Neidhöfer, M.; Landfester, K.; Iván, B.; Spiess, H. W. Macromolecules 2003, 36, 9107-9114. https://doi.org/10.1021/ma034891h

\section{Összefoglalás}

Az amfifil polimer kotérhálók (APCN) a nanoszerkezetü térhálós polimerek egy különleges csoportját képezik. Ezekben az anyagokban egymással nem elegyedő hidrofil és hidrofób polimer láncok vannak egy térhálóba összekötve kovalens kötésekkel. Ez meggátolja a makroszkópikus fázisszétválást, és az emiatt széles összetételtartományban fellépő kölcsönösen folytonos nanoméretü fázisszeparáció számos teljesen újszerü, korábban nem létező hibrid anyag előállítására nyújt lehetőséget. Ez többek között eddig nem ismert nanohibrid anyagi rendszerek és bioanyagok, pl. szabályozott gyógyszerleadást biztosító mátrixok, létrehozását teszik lehetővé.

\section{Köszönetnyilvánítás}

Szeretnénk köszönetet mondani Szauer Juditnak (MTA TTK AKI) a pásztázó kalorimetriás (DSC), Dr. MedzihradszkySchweiger Hedvignek (Eötvös Loránd Tudományegyetem) pedig az elemanalízis mérésekért. Az anyagi támogatásért köszönetet mondunk az Országos Tudományos Kutatási Alapprogramoknak (OTKA K75182, K81592, K112094, T046759), a European Research Area Chemistry (ERA-Chemistry) programnak (OTKA NN116252), és a Kutatási és Technológiai Innovációs Alapnak (KTIA AIK 12-1-2012-0014), valamint az NMR-készülékért a GVOP-3.2.1.-2004.04.0210/3.0 projektnek.

13. Scherble, J.; Thomann, R.; Iván, B.; Mülhaupt, R. J. Polym. Sci., Part B: Polym. Phys. 2001, 39, 1429-1436. https://doi.org/10.1002/polb.1114

14. Schmidt, M.; Raidt, T.; Ring, S.; Gielke, S.; Gramse, C.; Wilhelm, S.; Katzenberg, F.; Krumm, C.; Tiller, J. C. Eur. Polym. J. 2017, 88, 562-574.

https://doi.org/10.1016/j.eurpolymj.2016.09.046

15. Kunzler, J.; Ozark, R. J. Appl. Polym. Sci. 1997, 65,1081-1089.

16. Hirt, T.; Lohmann, D.; Hopken, J.; Liu, Q. PCT Int. Patent Appl. WO9749740, 1997

17. Ajello, E. M.; Lohmann, D.; Hopken, J.; Domschke, A. PCT Int. Patent Appl. WO9917917, 1999

18. Weber, M.; Stadler, R. Polymer 1988, 29, 1064-1070. https://doi.org/10.1016/0032-3861(88)90016-X

19. Erdődi, G.; Iván, B. Chem. Mater. 2004, 16, 959-962. https://doi.org/10.1021/cm0345063

20. Kennedy, J. P.; Iván, B. Designed Polymers by Carbocationic Macromolecular Engineering: Theory and Practice, Hanser Publishers: Munich, New York, 1992.

21. Iván, B.; Kennedy, J. P. J. Polym. Sci., Part A: Polym. Chem. 1990, 28, 89-104. https://doi.org/10.1002/pola.1990.080280107

22. Pinchuk, L.; Wilson, G. J.; Barry, J. J.; Schoephoerster, R. T.; Parel, J. M.; Kennedy, J. P. Biomaterials 2008, 29, 448-460. https://doi.org/10.1016/j.biomaterials.2007.09.041

23. Fodor, Cs.; Kali, G.; Iván, B. Macromolecules 2011, 44, 4496-4502. https://doi.org/10.1021/ma200700m

24. Fodor, Cs.; Iván, B. J. Polym. Sci., Part A: Polym. Chem. 2011, 49, 4729-4734. https://doi.org/10.1002/pola.24972

25. Domján, A.; Fodor, Cs.; Kovács, Sz.; Marek, T.; Iván, B.; Süvegh, K. Macromolecules 2012, 45, 7557-7565. https://doi.org/10.1021/ma301533g

26. Fodor, Cs.; Domján, A.; Iván, B. Polym. Chem. 2013, 4, 3714-3724. https://doi.org/10.1039/c3py00299c 
27. Fodor, Cs.; Bozi, J.; Blazsó, M.; Iván, B. RSC Advances 2015, 5, 17413-17423. https://doi.org/10.1039/C4RA16881J

28. Fodor, Cs.; Stumphauser, T.; Thomann, R.; Thomann, Y.; Iván, B. Polym. Chem. 2016, 7, 5375-5385. https://doi.org/10.1039/C6PY00848H

29. Mezey, P. PhD értekezés, Eötvös Loránd Tudományegyetem, Budapest, 2009.

30. Mezey, P.; Domján, A.; Iván, B.; Németh, P.; Thomann, R.; Mülhaupt, R. Polym. Mater. Sci. Eng. 2010, 102, 500-501. Süvegh, K.; Domján, A.; Vankó, Gy.; Iván, B.; Vértes, A. Macromolecules 1998, 31, 7770-7775. https://doi.org/10.1021/ma980466q

31. Varga, B.; Szabó, Á.; Thomann, R.; Thomann, Y.; Mülhaupt, R.; Iván, B. publikálás alatt

32. Fodor, Cs. PhD értekezés, Eötvös Loránd Tudományegyetem, Budapest, 2011.
33. Iván, B.; Kennedy, J. P.; Mackey, P. US Patent 5,073,381, 1991

34. Iván, B.; Kennedy, J. P.; Mackey, P. ACS Symp. Ser. 1991, 469, 194-202. https://doi.org/10.1021/bk-1991-0469.ch018

35. Iván, B.; Kennedy, J. P.; Mackey, P. ACS Symp. Ser. 1991, 469, 203-212. https://doi.org/10.1021/bk-1991-0469.ch019

36. Osváth, Zs.; Tóth, T.; Iván, B. Macromol. Rapid. Commun. 2017, 38, 1600724. https://doi.org/10.1002/marc.201600724

37. Haraszti, M.; Tóth, E.; Iván, B. Chem. Mater. 2006, 18, 4952-4958. https://doi.org/10.1021/cm061119v

38. Kali, G.; Iván, B. Macromol. Chem. Phys. 2015, 216, 605-613. https://doi.org/10.1002/macp.201400478

39. Kali, G.; Iván, B. Eur. Polym. J. 2016, 84, 668-674. https://doi.org/10.1016/j.eurpolymj.2016.10.006

40. Pásztor, Sz.; Kali, G.; Iván, B. J. Polym. Sci., Part A: Polym. Chem. 2017, 55, 1818-1821 https://doi.org/10.1002/pola.28569

\section{Unique nanostructured amphiphilic polymer conetworks, their gels and nanohybrids}

Amphiphilic polymer conetworks belong to a rapidly emerging class of nanostructured materials. These macromolecular assemblies are composed of covalently bonded, otherwise immiscible hydrophilic and hydrophobic polymer chains. Considering the immiscibility of the components the synthesis of such cross-linked polymer structures is still a challenging research topic. Usually three methods are considered for the synthesis of amphiphilic conetworks: (1) the macromonomer method which utilizes di- or multifunctional macromonomers as cross-linkers in the course of copolymerization with suitable low molecular weight monomers; (2) sequential block copolymerization by quasiliving polymerizations to obtain amphiphilic block copolymers followed by cross-linking; (3) chain-chain coupling of di- or multifunctional polymers possessing opposite philicities. Examples for the macromonomer method include polyisobutylene, polytetrahydrofuran and poly(dimethylsiloxane) cross-linker containing amphiphilic conetworks (e.g. poly(2-hydroxyethyl methacrylate)-lpolyisobutylene, poly(N,N-dimethylacrylamide)-lpolyisobutylene and poly(N-vinylimidazole- $l$-polyisobutylene conetworks, where "-l-" means "linked by"). Conetworks synthesized by the coupling of poly(poly(ethylene glycol) methacrylate)- $b$-polyisobutylene- $b$-poly(poly(ethylene glycol) methacrylate triblock copolymers were obtained by the technique of the sequential block copolymerization and subsequent cross-linking. The chain-chain coupling method was used for the synthesis poly(ethylene glycol)polyisobutylene conetworks by coupling hydroxyl-telechelic three-arm-star polyisobutylene with isocyanate telechelic poly(ethylene glycol). All of the three preparation methods require conditions in which the components are miscible. This is usually achieved by either carrying out the cross-linking reaction in common solvents for all the components or by using protecting group chemistry and subsequent derivatization in the resulting gels to obtain the targeted amphiphilic conetworks. On the basis of structural investigations carried out by small-angle X-ray scattering (SAXS), small-angle neutron scattering (SANS) and spin diffusion solid state NMR measurements until now, it can be concluded that amphiphilic polymer conetworks possess unique nanostructured morphology with $\sim 2-50 \mathrm{~nm}$ average domain sizes. Differential scanning calorimetry (DSC) measurements also confirm the phase separated structure since two glass transitions, related to the two kinds of components, are observed on the DSC curves. However, the most striking observation by atomic force microscopy (AFM) indicates that the amphiphilic conetworks have bicontinuous (cocontinuous), mutually nanoconfined morphological arrangements in a broad composition range in contrast to block copolymers composed of immiscible polymer chain segments. The amphiphilic conetworks have indeed amphiphilic character as proven by their composition dependent swelling ability in both hydrophilic (water) and hydrophobic solvents. However, the amphiphilic conetworks show swelling kinetics considerably different from common hydrogels as experienced by the detailed study of the swelling behaviour of poly(N-vinylimidazole)-l-polytetrahydrofuran conetworks. One of the most interesting characters of amphiphilic polymer conetworks is related to the concept according to which the bicontinuous nanophasic structure of amphiphilic conetworks can be utilized as nanoreactor for obtaining a large variety of novel nanohybrids not existed so far. For instance, selectively swelling one of the nanophases, e.g. the hydrophilic phase with metal ion solutions, followed by a selected reaction, such as reduction, in the swollen phase results in targeted nanohybrids. On the basis of these principles, we have been able to prepare a variety of conetwork-metal nanohybrids with nanoparticles of salts and metals, such as cadmium sulfide, silver, gold, copper, palladium etc. Some of them was found as highly efficient nanocatalyst in a well-known model reaction. Recently, novel organic-inorganic hybrid conetworks with thermoresponsive behavior in the range of body temperature were obtained by utilizing sol-gel chemistry between trimethoxysilyl-functionalized poly(Nisopropylacrylamide) and tetraethoxysilane (TEOS). These hybrid conetworks were tested as drug release matrices which provide composition and temperature controlled drug release. 